\title{
Lanthanum Staining of Coronary Microvascular Endothelium: Effects of Ischemia Reperfusion, Propranolol, and Atenolol
}

\author{
D. W. HaAck, L. R. Bush, M. Shlafer, and B. R. Lucchesi \\ Department of Physiology, University of Arizona College of Medicine, Tucson, Arizona 85724, and \\ Department of Pharmacology and Upjohn Center for Clinical Pharmacology, University of \\ Michigan, Ann Arbor, Michigan 48109
}

Received June 24, 1980

\begin{abstract}
Cat isolated hearts were perfused via the aorta with normothermic arterial blood from donor cats. After $1 \mathrm{hr}$ of equilibration, $d l$-propranolol $(1.9 \mathrm{mg} / \mathrm{kg})$, atenolol $(1.65 \mathrm{mg} / \mathrm{kg})$, or physiological saline solution was infused via the aortic cannula. The hearts were made globally ischemic for $1 \mathrm{hr}$ and reperfused for $1 \mathrm{hr}$. Hearts given saline but not made ischemic, and hearts from blood-donor cats served as controls. The hearts were flushed with physiological saline for $2 \mathrm{~min}$, then perfused with cacodylate-buffered glutaraldehyde containing $1 \% \mathrm{LaCl}_{3}$. Samples of left ventricle were postfixed in osmium and prepared for electron microscopy. Microvessels in nonischemic tissues had heavy $\mathrm{La}^{3+}$ staining on luminal surfaces of endothelial cells. Many plasmalemmal vesicles along luminal surfaces of endothelial cells were filled with $\mathrm{La}^{3+}$. Several vesicles appeared to open onto both surfaces thus forming channels through the endothelium. Lanthanum penetrated into, and occasionally through, interendothelial junctions. Endothelial cells lining vessels in ischemic myocardium were swollen, had pale cytoplasm, and showed little $\mathrm{La}^{3+}$ on the luminal surfaces. Few plasmalemmal vesicles were present and the mitochondria contained deposits of $\mathrm{La}^{3+}$. Extravascular spaces were distended but interendothelial junctions seemed to be intact. Lanthanum staining and morphology of endothelial cells in hearts treated with propranolol or atenolol were very similar to nonischemic myocardium. The data suggest that the $\beta$-blocking agents, propranolol and atenolol, maintain the integrity of coronary vascular endothelium during ischemia.
\end{abstract}

\section{INTRODUCTION}

Much of the research on myocardial ischemia has been aimed at preservation of myocardial function upon restoration of an adequate blood supply to the affected area. The structure and function of the myocardium after ischemia and reperfusion have been studied by a number of investigators (Althaus et al., 1977; Apstein et al., 1978; Bulkley and Hutchins, 1977; Burton et al., 1977; Bush et al., 1980b, c; Gaasch et al., 1978; Jennings and Ganote, 1974, 1976). However, little attention has been directed toward the structure of the myocardial vasculature. Ischemia has been reported to cause swelling of endothelial cells in the coronary microcirculation and to increase endothelial permeability (Poche, 1969; Kloner et al., 1974, 1977; Meneely, 1974; Gavin et al., 1978). Preservation of microvascular integrity is central to the maintenance of myocardial function after ischemic episodes for several reasons. First, an intact microvasculature would allow an 
adequate blood supply to the affected tissue to be reestablished easily. Second, preservation of microvascular integrity would protect the microenvironment within which the myocardial cells exist. This would directly support the function of the myocardial cells. Finally, an intact microvasculature would allow for better delivery of cardioprotective drugs to the affected tissues.

Lanthanum has been used to study the effects of cations on cellular function (Weiss, 1974; Dunnett et al., 1978; Mela, 1968; Langer and Frank, 1974), the structure of intercellular junctions (Revel and Karnovsky, 1967), the structure and composition of the external cell surface (Doggenweiler and Frenk, 1965; Frank et al., 1977; Lesseps, 1967; Martinez-Palomo et al., 1973; Shea, 1971), and the permeability of blood vessels (Huttner et al., 1975; Jokelainen et al., 1976). Recently lanthanum has been used as a probe of myocardial cell membrane integrity after ischemic episodes (Burton et al., 1977; Hoffstein et al., 1975) and as a test of the ability of various pharmacologic agents to protect myocardial cells from the effects of ischemia and reperfusion (Burton et al., 1980; Bush et al., $1980 \mathrm{a}, \mathrm{b})$. The $\beta$-adrenergic antagonists, propranolol and atenolol, have been shown to protect the structure and function of myocardial cells during ischemia and reperfusion (Reimer et al., 1976; Bush et al., 1980a, b; Shlafer $e t$ al., 1980) but the mechanism of this protection is not known. In addition, the significance of endothelial disruption in the course of several pathologic processes recently has been reviewed (Thorgeirsson and Robertson, 1978). However, the role of the coronary microvascular endothelium in the damage produced by myocardial ischemia and reperfusion is not known. Therefore, the purpose of the present study was to use ionic lanthanum to probe the integrity of endothelial cells lining the coronary microvasculature after global cardiac ischemia and reperfusion with or without pretreatment with $\beta$-adrenergic antagonists. $\Lambda$ preliminary report of this work has been presented (Haack et al., 1980).

\section{MATERIALS AND METHODS}

Isolated heart preparation. The cat isolated heart preparation used in this study was identical to that described by Vogel et al. (1979). Hearts were taken from 1- to $2-\mathrm{kg}$ cats which had been anesthetized with pentobarbital $(30 \mathrm{mg} / \mathrm{kg}$, ip). The hearts were perfused via the aorta with arterial blood drawn from $2.5-$ to $3.5-\mathrm{kg}$ cats which had been anesthetized with dial urethane $(0.7 \mathrm{ml} / \mathrm{kg}$, ip). The dial urethane was prepared as a solution containing $100 \mathrm{mg} / \mathrm{ml}$ allobarbital, $400 \mathrm{mg} / \mathrm{ml}$ urethane, and $400 \mathrm{mg} / \mathrm{ml}$ monoethyl urea. Perfusion pressure to the isolated hearts was maintained between $70-90 \mathrm{~mm} \mathrm{Hg}$ by means of a roller pump. Left ventricular developed pressure was maintained at $150 \mathrm{~mm} \mathrm{Hg}$ by adjusting the volume of a saline-filled balloon that had been placed in the left ventricle. The hearts were electrically paced at 150 beats per minute. Coronary effluent blood collected from the isolated heart by means of a cannula in the pulmonary artery was returned to the blood-donor cat via a cannula in its jugular vein. Isolated hearts were allowed to equilibrate for $1 \mathrm{hr}$.

Experimental protocol. After the equilibration period $d l$-propranolol $(1.9 \mathrm{mg} / \mathrm{kg}$ donor-cat body $\mathrm{wt})$, atenolol $(1.65 \mathrm{mg} / \mathrm{kg}$ donor-cat body $\mathrm{wt})$, or saline $(0.15$ $\mathrm{ml} / \mathrm{min} / 10 \mathrm{~min}$ ) was injected into the aortic cannula of the isolated heart by a 


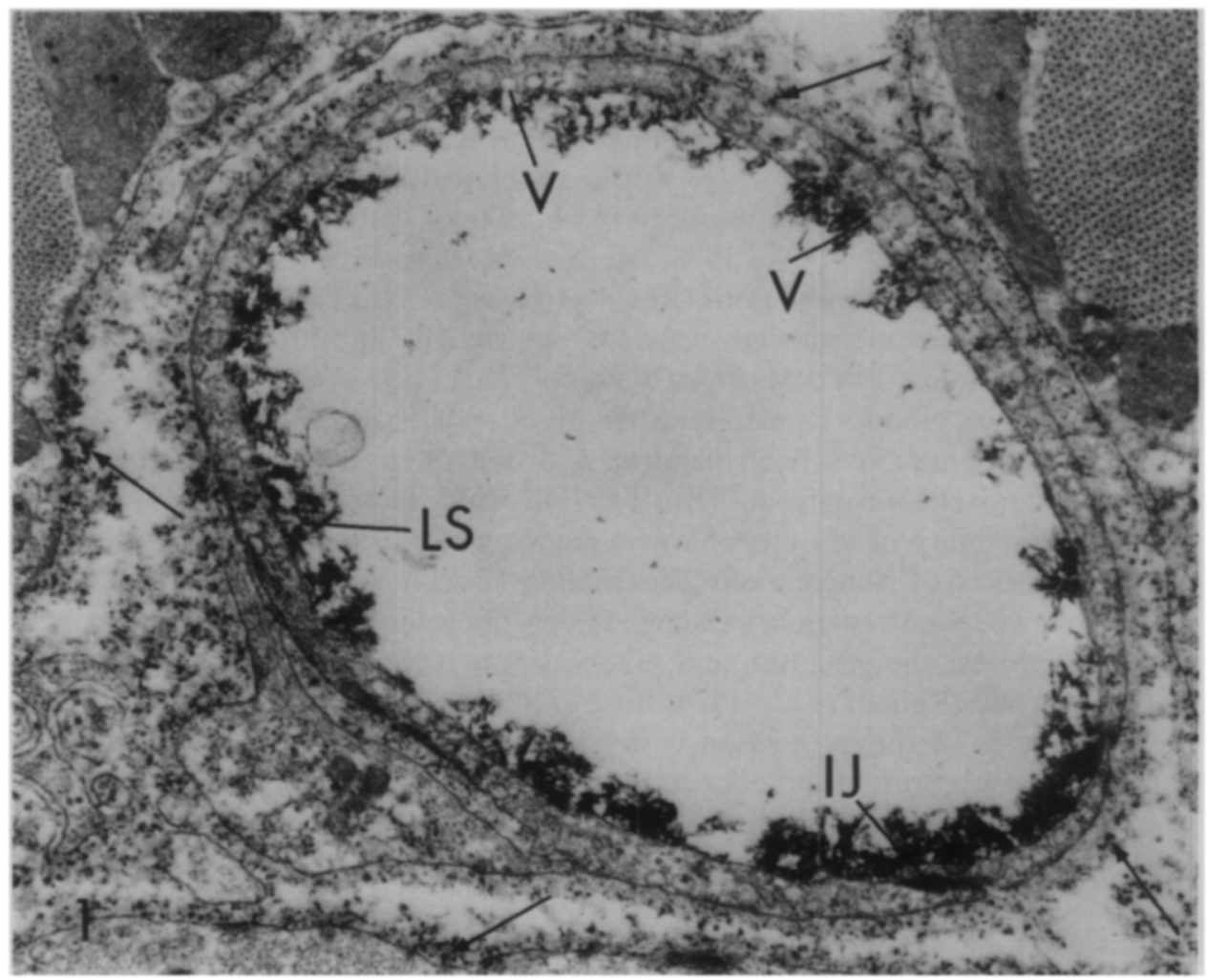

FIG. 1. Nonischemic control. The luminal surface (LS) of this capillary has been lightly stained with $\mathrm{La}^{3+}$. The filamentous nature of the endocapillary layer is apparent. Lanthanum has penetrated into the interendothelial junction (IJ) but not into the cytoplasmic vesicles (V). Although $\mathrm{La}^{3+}$ may be seen in the basal laminae of the endothelial and myocardial cells (arrows) none has entered the cells. $20,400 \times$.

Harvard infusion pump. The latter group of hearts served as nontreated ischemic controls. The hearts were then exposed to $1 \mathrm{hr}$ of normothermic ischemia by turning off the perfusion pump. Hearts that were given saline but not made ischemic, and hearts from the blood-donor cats, served as normal controls. Following the ischemic episode the hearts were reperfused for $1 \mathrm{hr}$. There were at least five hearts per group. One hour of global normothermic ischemia followed by an hour of reperfusion causes nearly a $60 \%$ decline in contractility and compliance (Vogel et al., 1979; Apstein et al., 1978). In similar models normothermic ischemia also has been shown to produce significant disruptions of myocardial function and ultrastructure (Apstein et al., 1977; Gillette et al., 1979).

Electron microscopy. After the reperfusion period two hearts were selected at random from each group. Each heart was given a code number to obscure the identity of the group from which it was obtained. The numbers were not decoded until data collection had been completed. The hearts were perfused with oxygenated physiological saline, $30^{\circ}$, for $2 \mathrm{~min}$. During this time the intraventricular diastolic pressure was adjusted to $10 \mathrm{~mm} \mathrm{Hg}$. The saline solution contained (in 


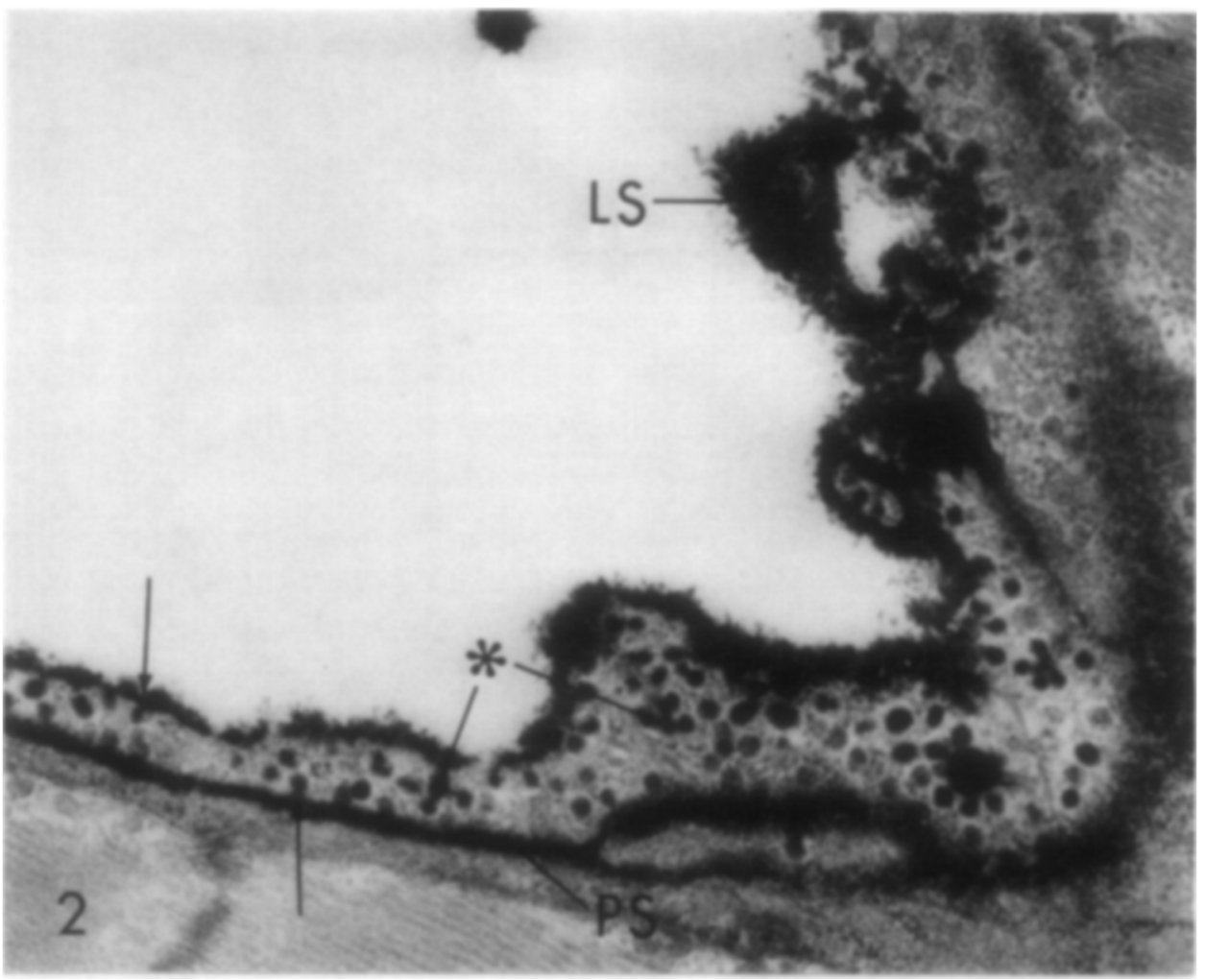

FIG. 2. Nonischemic control. This is an oblique section of a capillary. Lanthanum has uniformly stained the luminal surface (LS) and has entered the perivascular space (PS). The presence of $\mathrm{La}^{3+}$ in the vesicles indicates that they open onto the cell surface either directly (arrows) or via complex interconnections $\left({ }^{*}\right) .26,300 \times$.

$\mathrm{mM}): \mathrm{NaCl}, 140 ; \mathrm{KCl}, 5 ; \mathrm{MgCl}_{2}, 1.2 ;$ glucose, $10 ; \mathrm{CaCl}_{2}, 1.8$; and Tris buffer, 5 , pH 7.4. Then the hearts were pefused with $0.1 \mathrm{M}$ sodium cacodylate containing $2.5 \%$ glutaraldehyde and $1 \% \mathrm{LaCl}_{3}$. The $\mathrm{pH}$ of the fixative was 7.4 and the temperature was $25^{\circ}$. Perfusion pressure was maintained between 65 and $75 \mathrm{~mm} \mathrm{Hg}$ during the saline rinse and fixation. Fixative was perfused through the hearts for 3 min and then the hearts were immersed in fixative. The hearts were weighed and tissue samples were obtained from left ventricular papillary muscles and subendocardium. Tissue samples were cut into cubes 1-2 $\mathrm{mm}$ on a side and reimmersed in fixative at $25^{\circ}$. Total fixation time was $2 \mathrm{hr}$. The tissue samples were stored

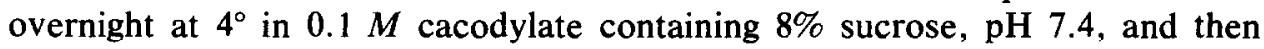
postfixed in cacodylate-buffered $1 \%$ osmium tetroxide for $1 \mathrm{hr}$. After dehydration in ethanol and propylene oxide, and embedding in Epon, the tissue blocks were mounted on Epon posts and sectioned with an LKB-Huxley ultramicrotome. Thick sections mounted on glass slides and stained with toluidine blue were examined with a light microscope to determine the orientation of the tissue. The tissue blocks were oriented so that capillaries would be sectioned transversely rather than longitudinally, because identification of capillaries is easier when the 


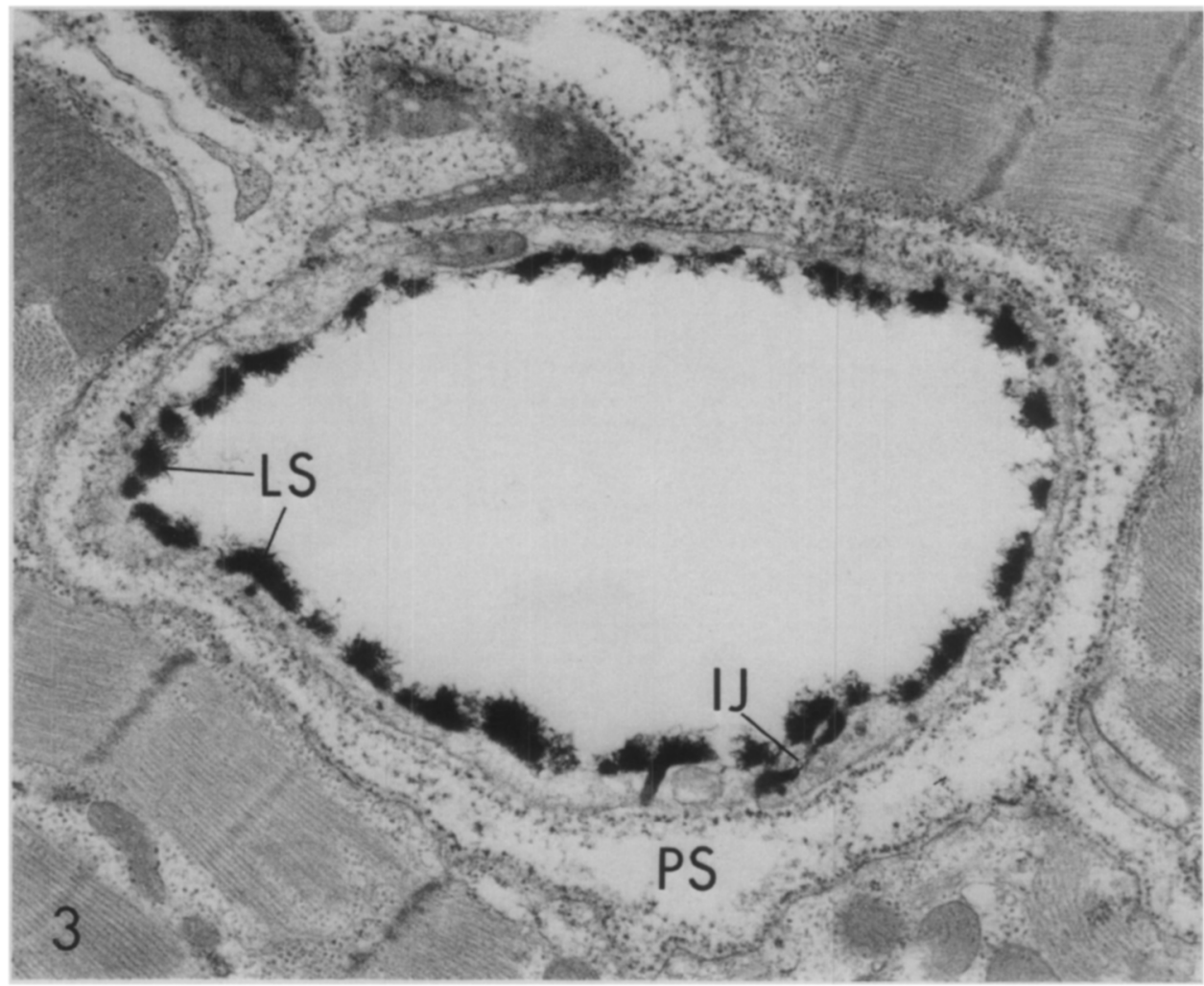

FIG. 3. Blood-donor heart. The luminal surface (LS) of this capillary has been heavily stained with $\mathrm{La}^{3+}$. Lanthanum is also present in the interendothelial junction (IJ) and on basal laminae in the perivascular space (PS). $15,400 \times$.

vessels have been cut in cross section. At least three blocks from each tissue sample were sectioned for electron microscopy. Thin sections were mounted on copper grids and examined with a Siemens 101 electron microscope. Both nonstained sections and sections that had been stained with uranyl acetate and lead citrate were studied. No differences in lanthanum distribution were noted between stained and unstained sections.

\section{RESULTS}

The endothelial cells surrounding capillaries in nonischemic control hearts and in hearts from blood-donor cats (Figs. 1-4) were very similar in morphology to capillaries described by others (Fawcett and McNutt, 1969; Sherf et al., 1977; Rhodin, 1974; Simionescu and Simionescu, 1977). The endothelium formed a layer of uniform thickness, except in the region of the nucleus, around an ovoid-tocircular lumen. One or two interendothelial junctions were present in each capillary. The endothelial cells contained a small number of mitochondrial profiles and many plasmalemmal vesicles. Each capillary was surrounded by a basal lamina. Occasionally the perivascular space was so compact that the basal laminae of the endothelial and myocardial cells appeared to be fused (Fig. 2). 


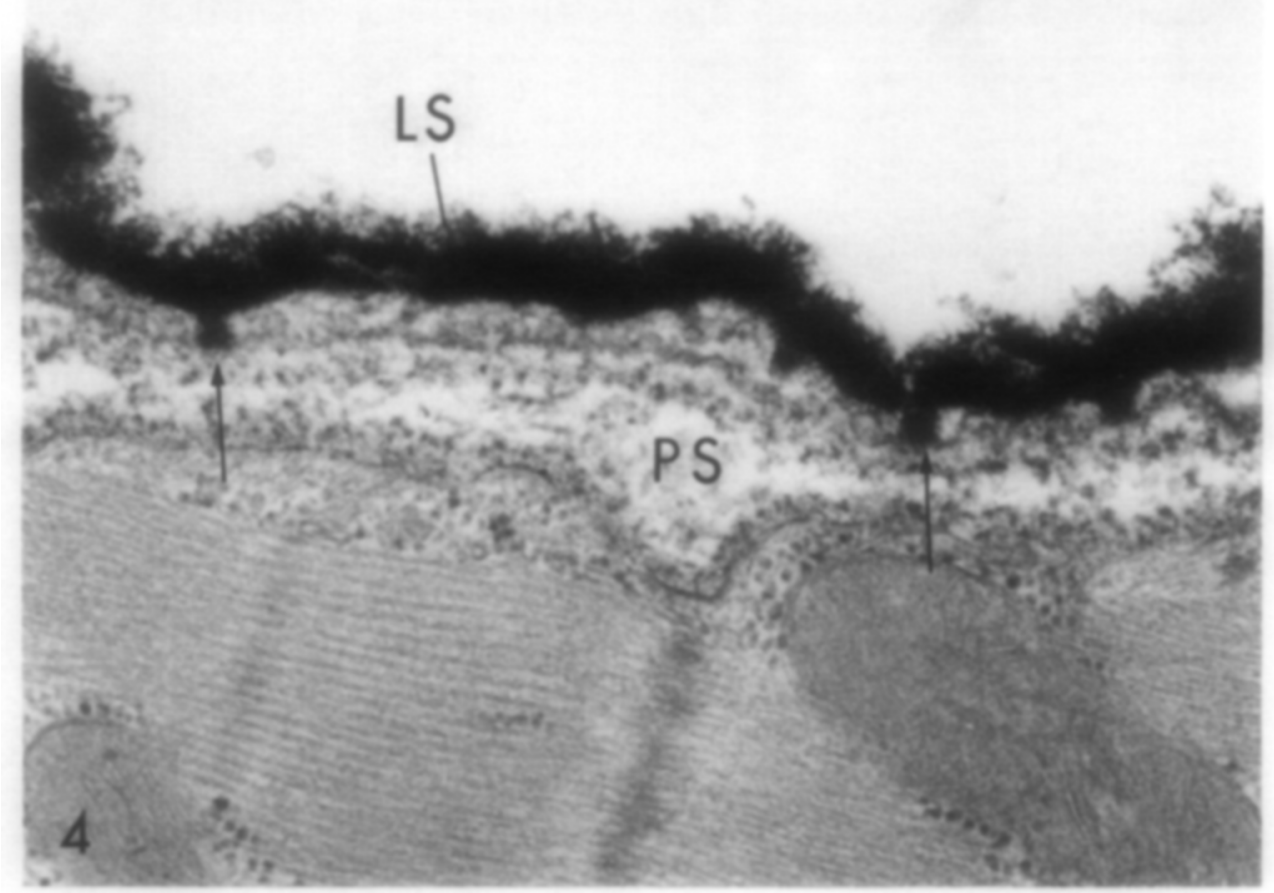

FIG. 4. Blood-donor heart. The endocapillary capillary coat on the luminal surface (LS) of the endothelial cell is heavily stained with $\mathrm{La}^{3+}$. The perivascular space (PS) is very narrow. Several lanthanum-filled vesicles appear to bridge the cytoplasm of this endothelial cell. $36,400 \times$.

The most striking feature of these vessels was the presence of a filamentous coat on the luminal surfaces of the endothelial cells (Figs. 1-4). This coat was especially prominent due to its staining by lanthanum. Lanthanum also was present on the basal laminae in the perivascular spaces. In many vessels lanthanum was present in the endothelial plasmalemmal vesicles (Figs. 2-4) as well as the interendothelial junctions (Figs. 1 and 3). However, it was not possible to determine whether lanthanum had reached the perivascular spaces via interendothelial junctions or channels through the endothelial cells formed by plasmalemmal vesicles (Fig. 4). No lanthanum was observed within the endothelial cells of capillaries in control hearts.

In contrast to the control capillaries, microvessels in hearts that had been ischemic for $1 \mathrm{hr}$ and reperfused for another hour were poorly preserved (Figs. 5 and 6). The most striking difference between control and ischemic capillaries was the absence of lanthanum staining from the luminal surfaces of capillaries in the ischemic hearts. In addition, endothelial cells in ischemic hearts were swollen, had pale-staining cytoplasm, and indistinct or disrupted plasma membranes. Some endothelial cells contained few plasmalemmal vesicles (Fig. 6) whereas others were replete with vesicles (Fig. 5). Dense accumulations of lanthanum were located 


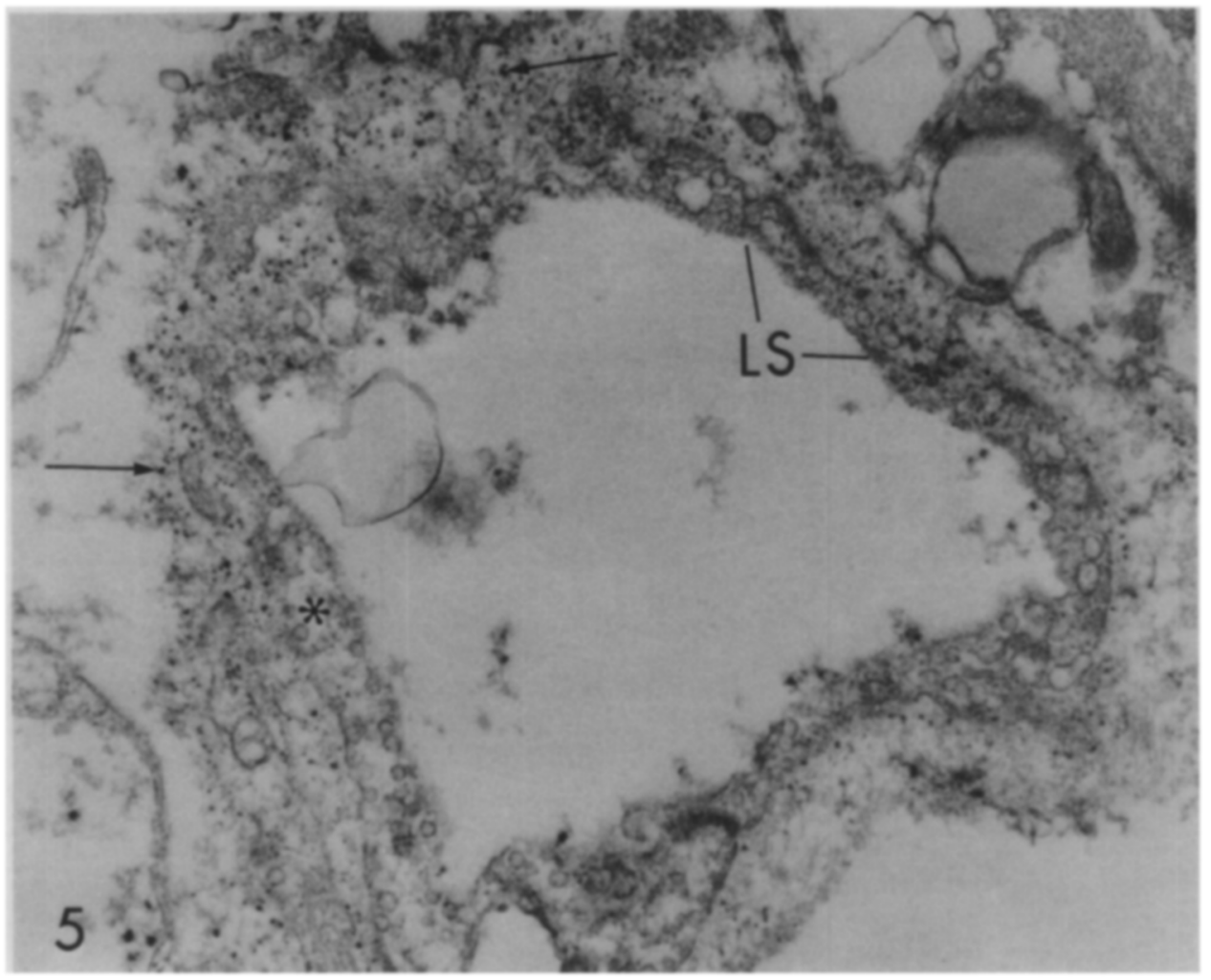

FIG. 5. Ischemia reperfusion, no drugs. The most striking feature of this micrograph is the lack of either $\mathrm{La}^{3+}$ or a filamentous coat on the luminal surface (LS) of this vessel. Lanthanum is present in the perivascular connective tissue (arrows). Both cells have indistinct or disrupted membranes and one cell (*) appears to be swollen. $21,500 \times$.

in mitochondria of many endothelial cells (Fig. 6). Lanthanum staining of the basal laminae was not markedly increased but the perivascular spaces were distended. In spite of extensive disruption of the endothelial cells the interendothelial junctions appeared to be structurally intact.

The morphology of capillaries in hearts that had been treated with propranolol or atenolol was very similar to that of control capillaries (Figs. 7-10). The filamentous endocapillary coat was present and heavily stained with lanthanum. The endothelial cells were thin, well preserved and filled with plasmalemmal vesicles. The interendothelial junctions contained lanthanum but did not differ morphologically from those in capillaries from nonischemic control hearts. However, the perivascular spaces were somewhat wider than those observed in control tissues. Pretreatment with propranolol or atenolol attenuated the deleterious effects of ischemia and reperfusion on the myocardial microvasculature. There were no apparent differences between the hearts treated with propranolol and those treated with atenolol. 


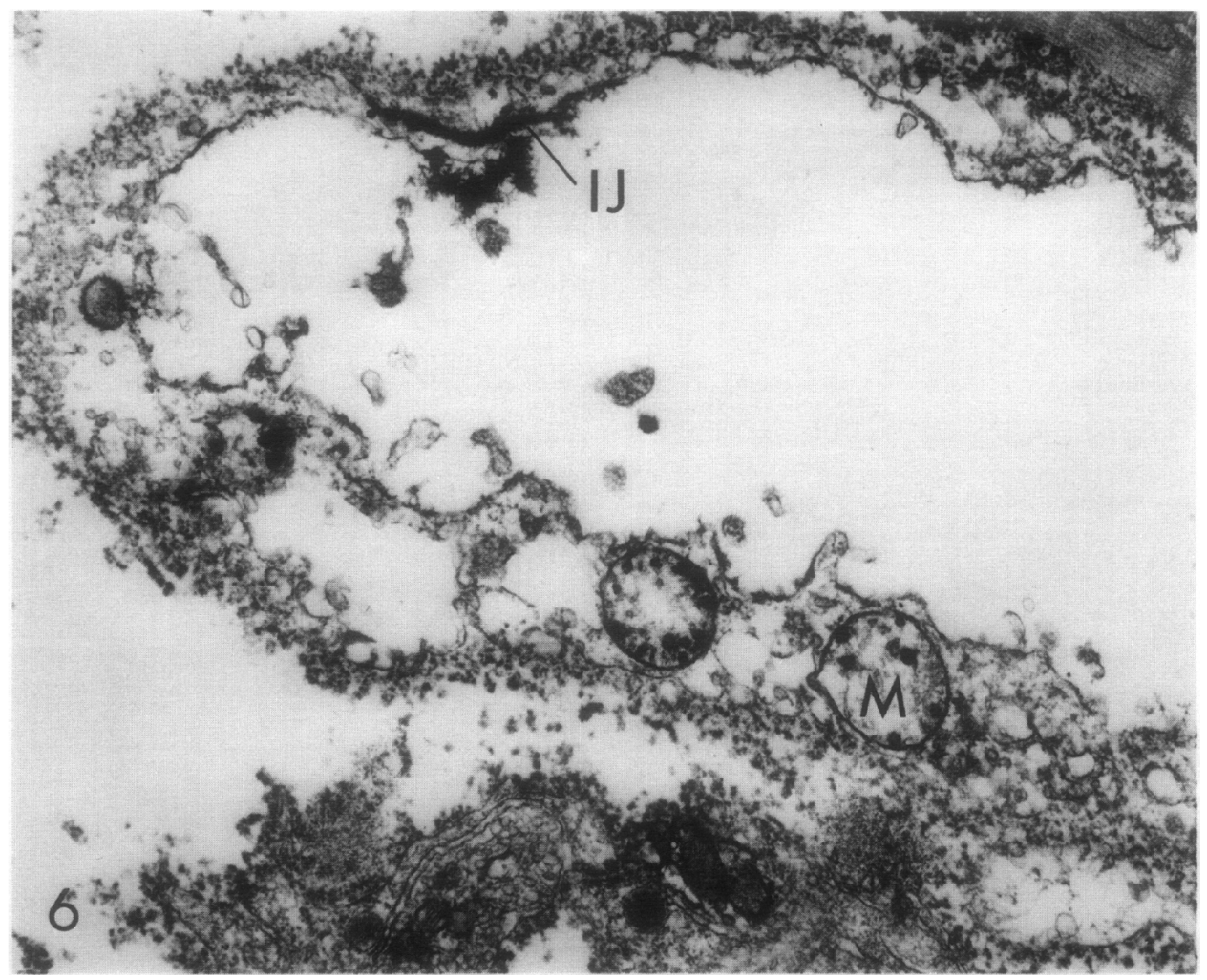

Fig. 6. Ischemia reperfusion, no drugs. The amount of $\mathrm{La}^{3+}$ on the luminal surface of this vessel is markedly reduced but $\mathrm{La}^{3+}$ is present in the interendothelial junction (IJ). Striking $\mathrm{La}^{3+}$ accumulations are apparent in the mitochondria (M) of the endothelial cell. Lanthanum is also seen in the perivascular space. The endothelial cells appear to have been thoroughly disrupted. $16,800 \times$.

\section{DISCUSSION}

The data presented in this report demonstrate that the luminal surfaces of myocardial capillary endothelial cells were covered by a fine filamentous layer which normally stains heavily with ionic lanthanum, but that after a period of ischemia and reperfusion this endocapillary layer was lost. In addition, the endothelial cells and surrounding myocardial cells were structurally disrupted after an episode of ischemia and reperfusion. However, treatment of hearts with propranolol or atenolol prior to the period of ischemia and reperfusuion prevented the loss of the endocapillary layer and attenuated the damage to both endothelial and myocardial cells (Bush et al., 1980a, b). The $\beta$-blocking drugs also preserve myocardial cell function (Shlafer et al., 1980). These data confirm and extend observations made by Kloner and his co-workers (1977) concerning the ability of propranolol to protect the coronary microvasculature against the effects of ischemia followed by reperfusion. Although the mechanism of this protection is not 


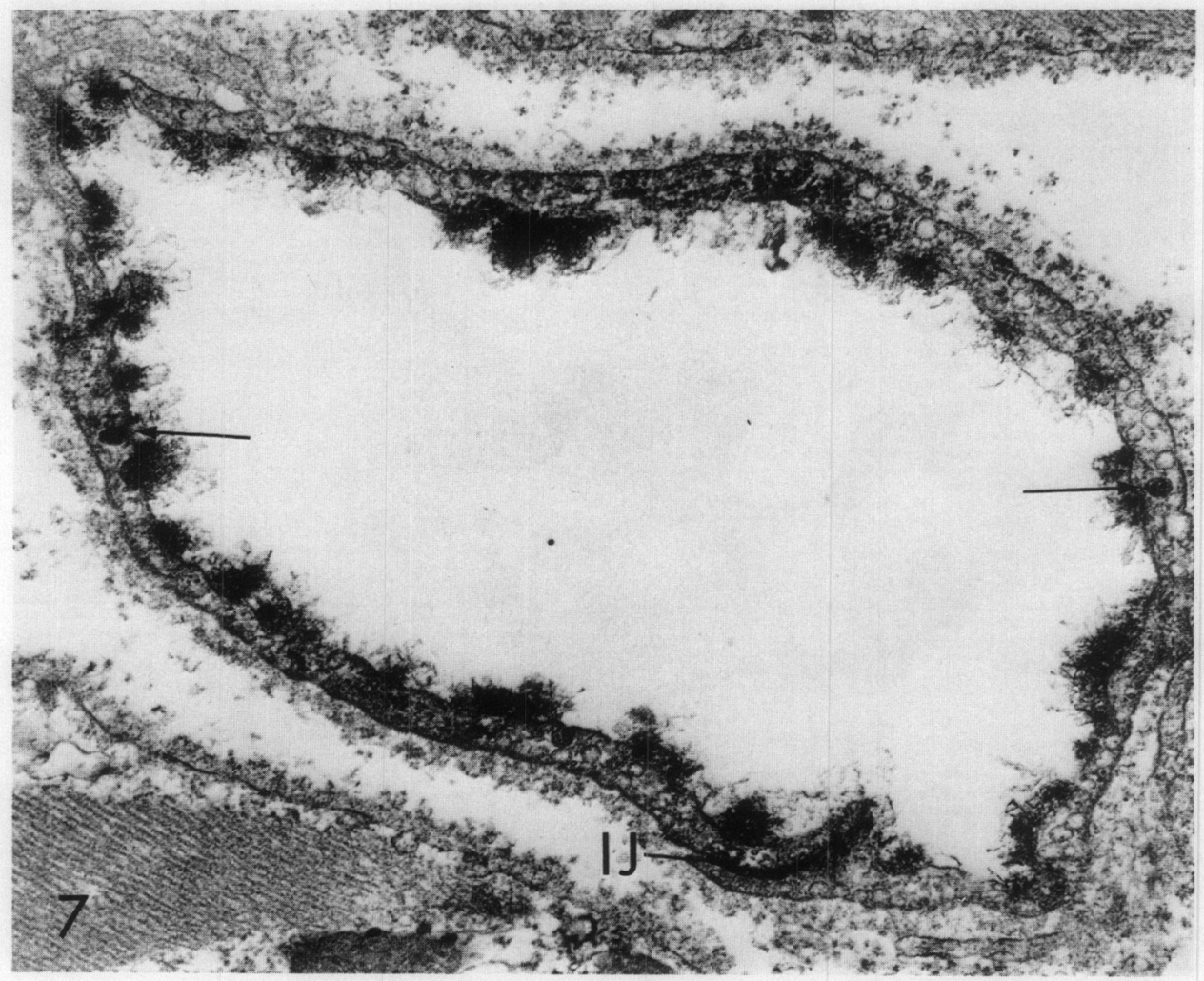

FIG. 7. Ischemia reperfusion, propranolol. The filamentous material on the luminal surface of this capillary has been well preserved and lightly stained with $\mathrm{La}^{3+}$. Lanthanum is present in the interendothelial junction (IJ) and a few vesicles (arrows) but little is present in the perivascular space. $24,400 \times$.

known, the data suggest that a relationship may exist between preservation of the endocapillary layer and maintenance of endothelial cell integrity.

The presence of a specific coat on the luminal surface of endothelial cells was postulated as early as 1947 by Chambers and Zweifach to explain some characteristics of capillary permeability. In 1965, Luft presented the first morphological evidence of such a coat and suggested that it consisted of acid mucopolysaccharides, indicating that the coat was not produced by accretion of plasma proteins onto the surfaces of the endothelial cells (Luft, 1966). More recently cationized ferritin has been used to confirm the existence of the luminal surface coat and to show that approximately half of the anionic sites in the coat were due to the presence of sialic acid residues (Skutelsky and Danon, 1976). Finally, the well-documented staining of cell surfaces by lanthanum (Doggenweiler and Frenk, 1965; Shea, 1971; Langer and Frank, 1972; Martinez-Palomo et $a l ., 1973)$ supports the concept that the lanthanum staining observed in the present study and in the work of Weihe et al. (1977) is due to interaction of lanthanum with anionic sites on the endothelial cell luminal surface. 

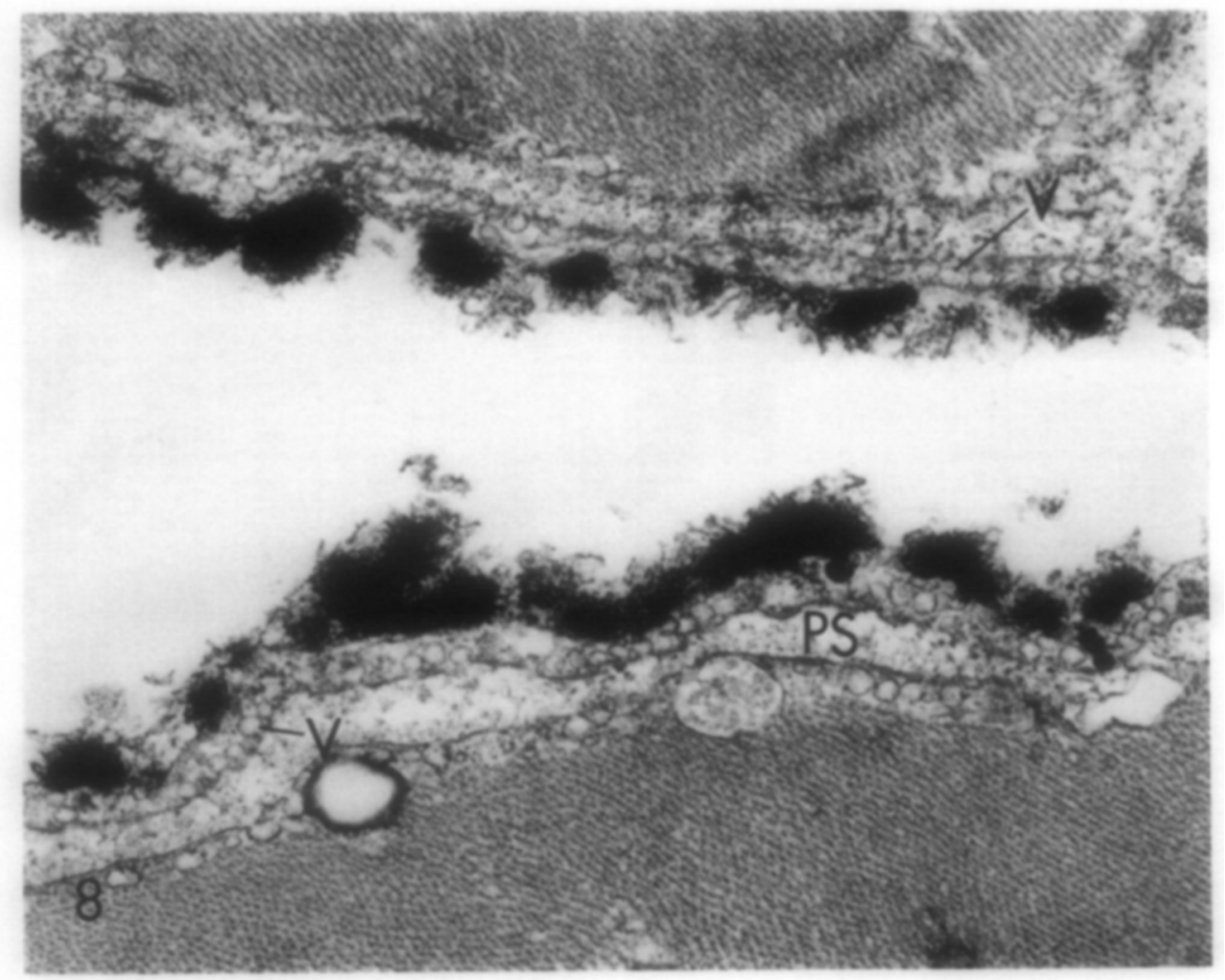

FIG. 8. Ischemia reperfusion, propranolol. A longitudinal section through a capillary. The material on the luminal surface has been well preserved and stained. Although many vesicles (V) are apparent only a few have been filled with $\mathrm{La}^{3+}$. The perivascular space (PS) is compact and contains very little lanthanum. $24,400 \times$.

The function of the endothelial luminal coat, or endocapillary layer, is not completely known (Thorgeirsson and Robertson, 1978) but Becker and Harpel (1976) have proposed that it may play a role in maintaining endothelial cell integrity. This endothelial coat is apparently very fragile and consequently is lost during routine preparation of tissues for electron microscopy (Luft, 1966). Therefore the endocapillary layer is rarely seen in electron micrographs. The presence of lanthanum in perfusates and fixatives seems to stabilize this layer and to increase its electron opacity. The apparent lability of the endocapillary layer and the proposed role of the layer in protecting the endothelium from blood-borne elements suggests that loss of the luminal coat may be an early event in the course of endothelial damage produced by ischemia and reperfusion. Conformation of this hypothesis awaits a careful examination of the sequence of endothelial cell changes induced by ischemia and reperfusion.

Restoration of adequate blood flow to an ischemic area of myocardium is essential for support of compromised cells and repair of damaged tissue. However, reperfusion of the ischemic myocardium may not change the course of the pathologic process (Althaus et al., 1977) and may produce further damage 

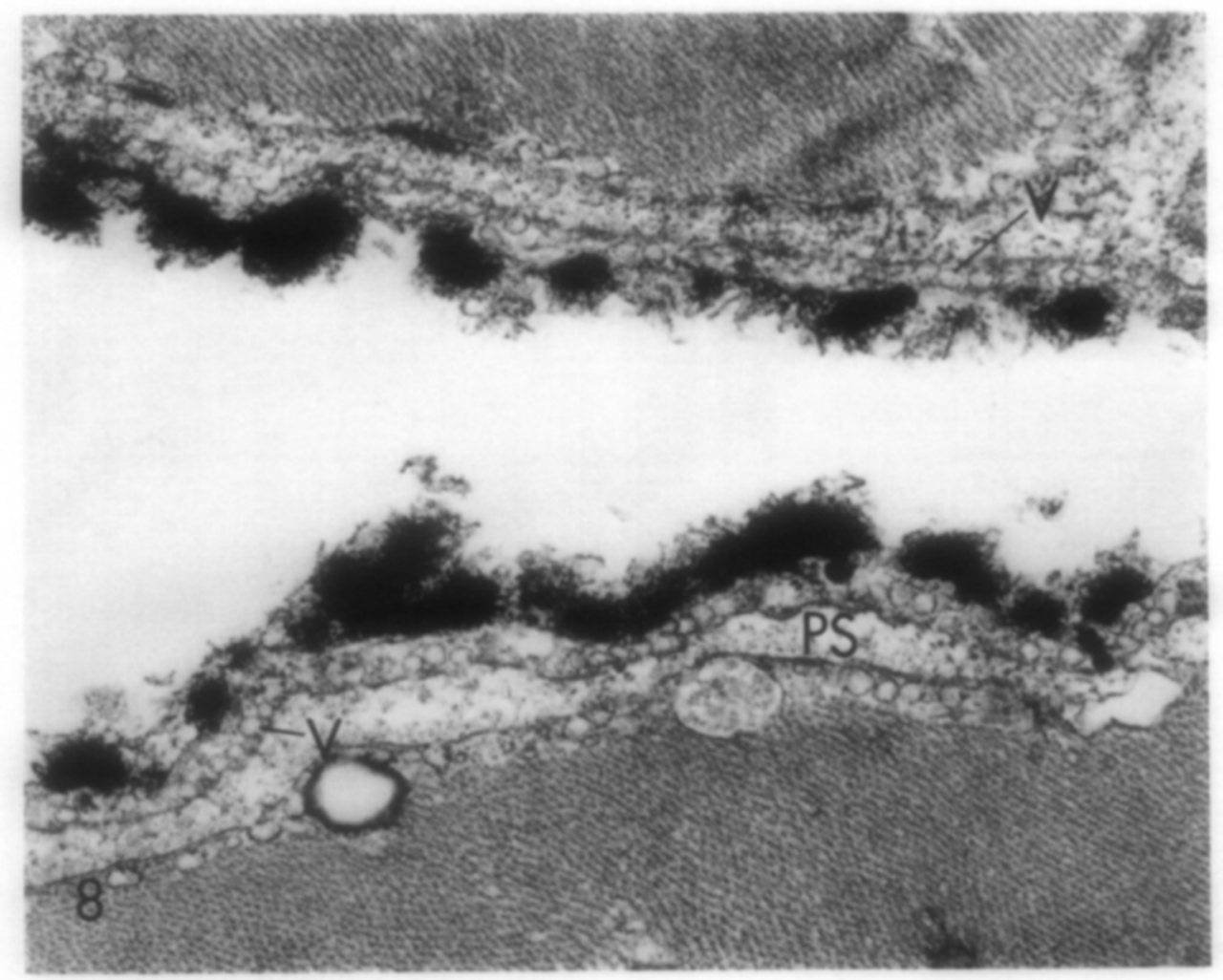

FIG. 9. Ischemia reperfusion, atenolol. As in capillaries from propranolol-treated hearts the endothelium in this capillary has been well preserved and its luminal surface (LS) has been heavily stained with $\mathrm{La}^{3+}$. Lanthanum has penetrated into the interendothelial junction (IJ) and a few vesicles (arrows) but little is present in the perivascular space. 17,150×.

(Bulkley and Hutchins, 1977; Jennings and Ganote, 1976; Vatner et al., 1978). Upon restoration of blood flow to an ischemic area there is an abnormal retention of fluid and ions (Willerson et al., 1977; Whalen et al., 1974) as well as an increase in the permeability of myocardial cell membranes (Burton et al., 1977; Bush et al., $1980 \mathrm{a}, \mathrm{b})$. Morphologically the effects of ischemia followed by reperfusion are expressed as swelling of the myocardial cells, swelling and eventual disruption of mitochondria, accumulation of lipid- and calcium-rich granules in mitochondrial matrices, and condensation of chromatin within myocardial cell nuclei (Jennings and Ganote, 1974, 1976; Kloner et al., 1974; Whalen et al., 1974).

The edema observed in the myocardium might be caused by increased permeability of the coronary microvasculature, since a number of insults, including anoxia, reportedly cause opening of interendothelial junctions (Constantinides and Robinson, 1969; Ryan and Majno, 1977), and several markers of vascular permeability have been found to move into injured myocardium (Meneely, 1974; Boutet et al., 1976; Kloner et al., 1977). However, few, if any, of the interendothelial junctions observed in the present study were disrupted. The junctions contained lanthanum but appeared to be structurally intact. The data support previous 


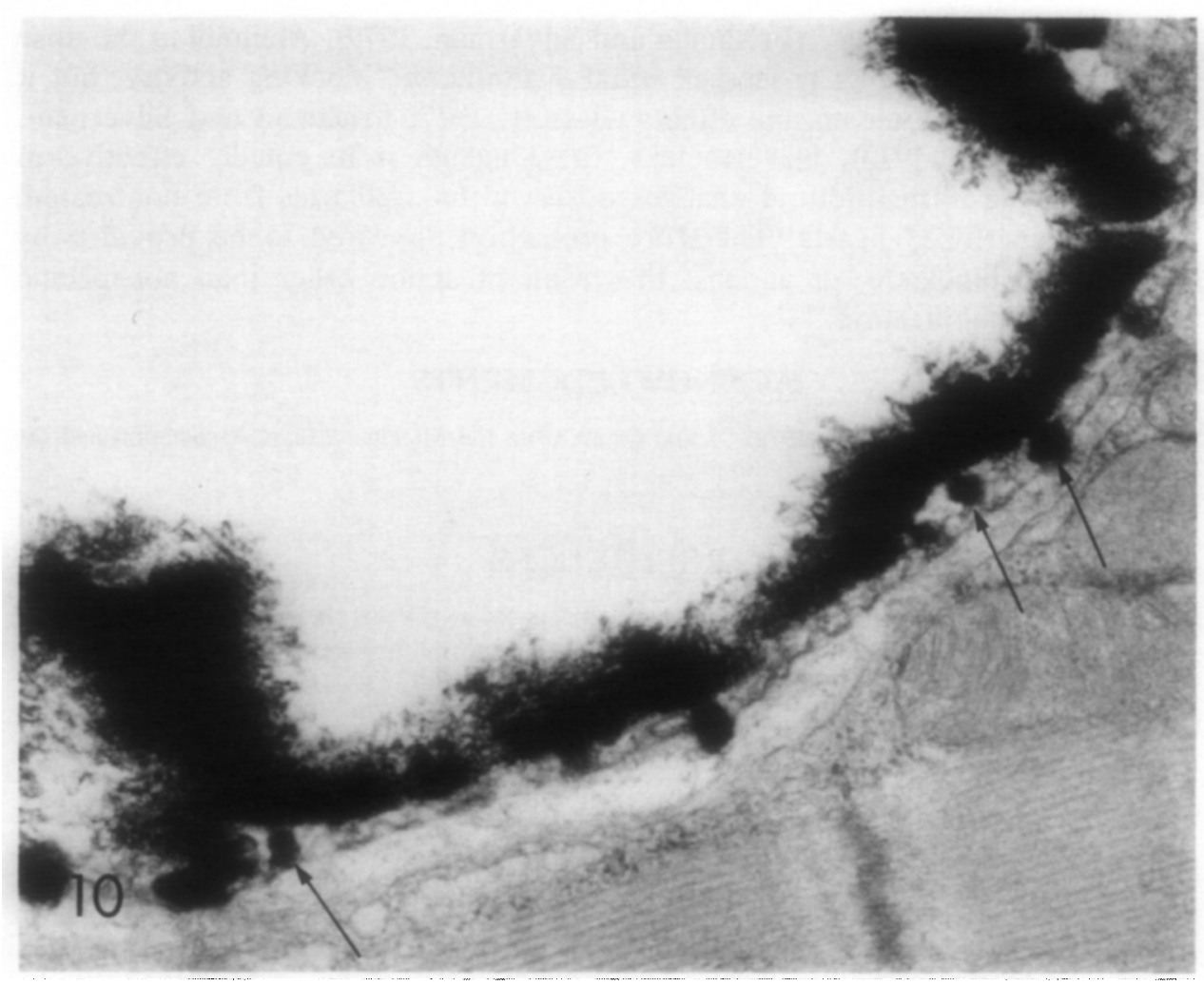

FIG. 10. Ischemia reperfusion, atenolol. The luminal surface of this capillary has bound a great deal of $\mathrm{La}^{3+}$. The perivascular space is compact and both the endothelial and myocardial cells appear to be intact. Several lanthanum-filled vesicles appear to bridge the endothelial cytoplasm (arrows) but very little lanthanum has entered the perivascular space. $27,000 \times$.

studies that also reported intact interendothelial junction in spite of ischemia (Armiger and Gavin, 1975; Gavin et al., 1978). There are two explanations for these differences. First, the increased permeation of the vasculature may occur by way of the disrupted endothelial cells. Second, different segments of the microvasculature differ in their permcability charactcristics (Simionescu et al., 1975), and although precise identification of the various microvascular segments is difficult (Simionescu et al., 1978; Johansson, 1979), the present study focused on capillaries rather than the more permeable postcapillary venules. Therefore "leaky" junctions would not have been found.

The $\beta$-adrenergic antagonist propranolol has been shown to reduce the size of myocardial infarcts (Maroko et al., 1972; Reimer et al., 1976) and to protect the coronary microvasculature from the effects of ischemia and reperfusion (Kloner $e t$ al., 1977). However, the mechanism of the protection is not known. To gain further insight into this problem the $\beta$-adrenergic antagonists, propranolol and atenolol, were compared for their relative actions in preserving the integrity of the myocardial microvasculature in the face of ischemia and reperfusion. Propranolol possesses negative ionotropic and chronotropic effects that are said to be due to 
"membrane stabilization" (Frishman and Silverman, 1979). Atenolol at the dose used in our experiments possesses equal $\beta$-adrenergic blocking activity, but it lacks propranolol's membrane effects (Barrett, 1977; Frishman and Silverman, 1979; Johansson, 1979). Nevertheless, these agents were equally effective in preventing the ultrastructural changes observed in capillaries from nontreated, ischemic-reperfused hearts. Therefore protection appeared to be provided by $\beta$-adrenergic blockade, or at least the result of action other than nonspecific "membrane stabilization."

\section{ACKNOWLEDGMENTS}

Supported by NIH Grant HL-19782-03 and grants from the Michigan Heart Association and the American Heart Association.

\section{REFERENCES}

Althaus, U., Gurtner, H. P., Baur, H., Hamburger, S., and Roos, B. (1977). Consequences of myocardial reperfusion following temporary coronary occlusion in pigs: Effects on morphologic, biochemical and haemodynamic findings. Eur. J. Clin. Invest. 7, 437-443.

Apstein, C. S., Deckelbaum, L., Hagopian, L., and Hood, W. B., Jr. (1978). Acute cardiac ischemia and reperfusion: Contractility, relaxation, and glycolysis. Amer. J. Physiol.: Heart Circ. Physiol. 4, H637-H648.

APstein, C. S., Mueller, M., And Hood, W. B., JR. (1977). Ventricular contracture and compliance changes with global ischemia and reperfusion, and their effect on coronary resistance in the cat. Circ. Res. 41, 206-217.

Armiger, L. C., ANd Gavin, J. B. (1975). Changes in the microvasculature of ischemic and infarcted myocardium. Lab. Invest. 33, 51-56.

Barrett, A. M. (1977). The pharmacology of atenolol. Postgrad. Med. J. 53(3), 58-64.

BECKER, C. G., AND HARPEL, P. C. (1976). $\alpha$ 2-Macroglobulin on human vascular endothelium. J. Exp. Med. 144, 1-9.

Boutet, M., Huttner, I., and Rona, G. (1976). Permeability alteration of sarcolemmal membrane in catecholamine-induced cardiac muscle cell injury. In vivo studies with fine structural diffusion tracer horseradish peroxidase. Lab. Invest. 34, 482-488.

Bulkley, B. H., ANd Hutchins, G. M. (1977). Myocardial consequences of coronary artery bypass graft surgery. The paradox of necrosis in areas of revascularization. Amer. J. Cardiol. 56, 906-913.

Burton, K. P., Hagler, H. K., Grecio, C. A., Willerson, J. T., and Buja, L. M. (1980). Functional and structural correlates of ischemia in isolated perfused myocardium: Effects of chlorpromazine. Fed. Proc. 39, 276 (abstr.).

Burton, K. P., Hagler, H. K., Templeton, G. H., Willerson, J. T., and Buja, L. M. (1977). Lanthanum probe studies of cellular pathophysiology induced by hypoxia in isolated cardiac muscle. J. Clin. Invest. 60, 1289-1302.

Bush, L. R., HaAck, D. W., Shlafer, M., and Lucchesi, B. R. (1980a). Prevention by propranolol or atenolol of ischemia-induced ultrastructural damage in isolated blood-perfused hearts. Fed. Proc. 39, 531 (abstr.).

Bush, L. R., HaAck, D. W., Shlafer, M., and Lucchesi, B. R. (1980b). Protective effects of $\beta$-adrenergic blockade in isolated ischemic hearts. Eur. J. Pharmacol. 67, 209-217.

Bush, L. R., Shlafer, M., HaAck, D. W., an D Lucchesi, B. R. (1980c). Time-dependent changes in canine cardiac mitochondrial function and ultra-structure resulting from coronary occlusion and reperfusion. Basic Res. Cardiol. 75, 555-571.

Chambers, R., ANd Zweifach, B. W. (1947). Intercellular cement and capillary permeability. Physiol. Rev. 27, 436-463.

Cunstantinides, P., ANd Robinson, M. (1969). Ultrastructural injury of arterial endothelium. I. Effects of pH, osmolarity, anoxia, and temperature. Arch. Pathol. 88, 99-105. 
Doggenweiler, C. F., ANd Frenk, S. (1965). Staining properties of lanthanum on cells membranes. Proc. Nat. Acad. Sci. USA 53, 425-430.

DunnetT, J., KAtz, A. M., and Nayler, W. G. (1978). Effects of lanthanum ions on calcium transport by guinea-pig, rat and canine sarcoplasmic reticulum. J. Mol. Cell. Cardiol. 10, $271-279$.

FAwCETT, D. W., AND McNuTt, N. S. (1969). The ultrastructure of the myocardium. I. Ventricular papillary muscle. J. Cell Biol. 42, 1-45.

Frank, J. S., Langer, G. A., Nudd, L. M., and Seraydarian, K. (1977). The myocardial cell surface, its histochemistry, and the effect of sialic acid and calcium removal on its structure and cellular ionic exchange. Circ. Res. 41, 702-714.

Frishman, W. (1979). Clinical pharmacology of the new beta-adrenergic blocking drugs. Part 1. Pharmacodynamic and pharmacokinetic properties. Amer. Heart J. 97, 663-670.

Frishman, W., ANd Silverman, R. (1979). Clinical pharmacology of the new beta-adrenergic blocking drugs. Part 3. Comparative clinical experience and new therapeutic applications. Amer. Heart J. 98, 119-131.

Gansch, W. H., Bing, O. H. L., Pine, M. B., Franklin, A., Clement, J., Rhodes, D., Phar, W. P., And Weintraub, R. M. (1978). Myocardial contracture during prolonged ischemic arrest and reperfusion. Amer. J. Physiol.: Heart Circ. Physiol. 4, H619-H627.

Gavin, J. R., Seeigf, R. N., Neval ainen, J. T., and Armiger, L. C. (1978). The effect of ischemia on the function and fine structure of the microvasculature of myocardium. Pathology 10, $103-111$.

Gillette, P. C., Pinsky, W. W., Lewis, R. M., Bornet, E. P., Wood, J. M., Entman, M. L., And SchWARTZ, A. (1979). Myocardial depression after elective ischemic arrest. J. Thorac. Cardiovasc. Surg. 77, 608-618.

HaAck, D. W., Bush, L. R., Shlafer, M., and Lucchesi, B. R. (1980). Lanthanum staining of coronary microvascular endothelium. Effects of ischemia, propranolol and atenolol. Fed. Proc. 39, 774 (abstr.).

Hoffstein, S. T., Gennaro, D. E., Fox, A. C., Hirsch, J,, Streuli, F., and Weissmann, G. (1975). Colloidal lanthanum as a marker for impaired plasma membrane permeability in ischemic dog myocardium. Amer. J. Pathol. 79, 206-217.

Huttner, I., Boutet, M., ANd More, R. H. (1973). Gap junctions in arterial endothelium. J. Cell Biol. 57, 247-252.

Jennings, R. B., and Ganote, C. E. (1974). Structural changes in myocardium during acute ischemia. Circ. Res. 34 and 35 (Suppl. III), III-156-III-172.

Jennings, R. B., ANd Ganote, C. E. (1976). Mitochondrial structure and function in acute myocardial ischemia. Circ. Res. 38 (Suppl. I), I-80-I-91.

JoHANSSON, B. (1979). Effects of atenolol, methaprolol, and pamatolol on cardiac and vascular beta-receptors in the rat. J. Cardiovasc. Pharmacol. 1, 287-298.

JoHANSSON, B. R. (1979). Size and distribution of endothelial plasmalemmal vesicles in consecutive segments of the microvasculature in cat skeletal muscle. Microvasc. Res. 17, 107-117.

Jokelainen, P. T., HaAck, D. W., and Rhodin, J. A. G. (1976). Permeability of arterial capillary endothelium. In "Microcirculation, Volume 2," (J. Grayson and W. Zingg, eds.), pp. 77-78. Plenum, New York.

Kloner, R. A., Fishbein, M. C., Cotran, R. S., Braunwald, E., and Maroko, P. R. (1977). The effect of propranolol on microvascular injury in acute myocardial ischemia. Circulation 55, 872-880.

Kloner, K. A., Ganote, C. E., and Jennings, R. B. (1974). The "no-reflow" phenomenon after temporary coronary occlusion in the dog. J. Clin. Invest. 54, 1496-1508.

LANGer, G. A., AND Frank, J. S. (1974). Lanthanum in heart cell culture. J. Cell Biol. 54, 441-455.

Lesseps, R. J. (1967). The removal by phospholipase $C$ of a layer of lanthanum staining material external to the cell membrane in embryonic chick cells. J. Cell Biol. 34, 173-183.

LuFT, J. H. (1965). Fine structure of capillaries: The endocapillary layer. Anat. Rec. 151, 380 (abstr.).

LuFT, J. H. (1966). Fine structure of capillary permeability and endocapillary layer as revealed by rethenium red. Fed. Proc. 25, 1773-1783.

Maroko, P. R., Libby, P., Covell, J. W., Sobel, B. E., Ross, J., JR., and Braunwald, E. (1972). Precordial ST segment elevation mapping: An atraumatic method for assessing alterations in the extent of myocardial ischemic injury. The effects of pharmacologic and hemodynamic interventions. Amer. J. Cardiol. 29, 223-230. 
Martinez-Palomo, A., Benitez, D., ANd Manis, J. (1973). Selective deposition of lanthanum in mammalian cardiac cell membranes. Ultrastructural and electrophysiological evidence. I. Cell Biol. 58, 1-10.

MelA, L. (1968). Interactions of $\mathrm{La}^{3+}$ and local anesthetic drugs with mitochondrial $\mathrm{Ca}^{2+}$ and $\mathrm{Mn}^{2+}$ uptake. Arch. Biochem. Biophys. 123, 286-293.

Meneely, G. R. (1974). The capillary factor in myocardial infarction. Amer. J. Cardiol. 34, 581-587.

PocHe, R. (1969). Ultrastructure of heart muscle under pathological conditions. Ann. N.Y. Acad. Sci. 156, 34-47.

Reimer, K. A., Rasmusen, M. M., And Jennings, R. B. (1976). On the nature of protection by propranolol against myocardial necrosis after temporary coronary occlusion in dogs. Amer. $J$. Cardiol. 37, 520-527.

ReVEL, J. P., AND KaRnovsky, M. J. (1967). Hexagonal array of subunits in intercellular junctions of the mouse heart and liver. J. Cell Biol. 33, C7-C12.

Rhodin, J. A. G. (1974). "Histology. A Text and Atlas," pp. 237 and 352-362. Oxford Univ. Press, New York.

Ryan, G. B., And Majno, G. (1977). Acute inflammation. Amer. J. Pathol. 86, 183-276.

SHEA, S. M. (1971). Lanthanum staining of the surface coat of cells: Its enhancement by the use of fixatives containing alcian blue or cetylpyridinium chloride. J. Cell Biol. 51, 611-620.

Sherf, L., Ben-Shaul, Y., AND Lieberman, Y. (1977). The human coronary microcirculation: An electron microscopic study. Amer. J. Cardiol. 39, 599-608.

Shlafer, M., Bush, L. R., AND LuCchesI, B. R. (1980). Prevention by propranolol or atenolol of ischemia-induced losses of contractile and subcellular function in isolated blood-perfused hearts. Fed. Proc. 39, 1002 (abstr.).

Simionescu, N., ANd Simionescu, M. (1977). The cardiovascular system. In "Histology" (L. Weiss and R. O. Greep, eds.), 4th ed., pp. 373-431. McGraw-Hill, New York.

Simionescu, M., Simionescu, M., and Palade, G. E. (1975). Segmental differentiation of cell junctions in the vascular endothelium: The microvasculature. J. Cell Biol. 67, 863-885.

Simionescu, M., Simionescu, N., and Palade, G. E. (1978). Structural basis of permeability in sequential segments of the microvasculature. I. Bipolar microvascular fields in the diaphragm. Microvasc. Res. 15, 1-16.

SKUTELSKY, E., AND DANON, D. (1976). Redistribution of surface anionic sites on the luminal front of blood vessel endothelium after interaction with polycationic ligand. J. Cell Biol. 71, 232-241.

Thorgeirsson, G., AND Robertson, A. L., JR. (1978). The vascular endothelium-pathobiologic significance. Amer. J. Pathol. 93, 801-848.

Vatner, S. F., Baig, H., Manders, W. T., and Maroko, P. R. (1978). Effects of coronary artery reperfusion on myocardial infarct size calculated from creatinine kinase. J. Clin. Invest. 61, 10481056.

Vogel, W. M., LUM, D., AND Lucchesi, B. R. (1979). Methylprednisolone sodium succinate treatment in global ischemia of the cat isolated heart. J. Cardiovasc. Pharmacol. 1, 53-68.

Weihe, E., Hartschuh, W., Metz, J., and Bruhl, U. (1977). The use of ionic lanthanum as a diffusion tracer and as a marker of calcium binding sites. Cell Tissue Res. 178, 285-302.

Weiss, G. B. (1974). Cellular pharmacology of lanthanum. Annu. Rev. Pharmacol. 14, 343-354.

Whalen, D. A., Hamilton, D. G., Ganote, C. E., and Jennings, R. B. (1974). Effects of a transient period of ischemia on myocardial cells. I. Effects on cell volume regulation. Amer. $J$. Pathol. 74, 381-398.

Willerson, J. T., Scales, F., Mukheruee, A., Platt, M., Templeton, G. H., Fink, G. S., and BujA, L. M. (1977). Abnormal myocardial fluid retention as an early manifestation of ischemic injury. Amer. J. Pathol. 87, 159-188. 